\title{
Influence of speculative operations on the investment capital: An empirical analysis of capital markets
}

\author{
Anna Slobodianyk ${ }^{1}$ and George Abuselidze ${ }^{2, *}$ \\ ${ }^{1}$ National University of Life and Environmental Science of Ukraine, Heroiv Oborony, 11, 03041, Kiev, Ukraine \\ ${ }^{2}$ Batumi Shota Rustaveli State University, Ninoshvili, 35, 6010, Batumi, Georgia
}

\begin{abstract}
The article is devoted to substantiation of significance of speculative operations and follows the goal to study their condition and development. The purpose of this article is to reveal the essence of the speculative component of the movement of investment capital in stock exchange. It is substantiated that existence and stability of the securities market plays a significant role in development of financial market, which in turn becomes a key element in the mechanism of economy. The authors emphasize that the liquid market continues to function even with a large number of economic agents while price fluctuation of securities have a little change. It has been established that speculation can be carried out on the stock exchange both using cash and in futures transactions. However, operating with cash transactions has fewer combinations and in general less profitable, thus the main arena of speculators becomes the market of future transactions. It has been proven that speculative profits are possible during both "bullish games" and in shorting's, thus becoming an important tool for additional attraction of investments. Consequently, speculations have a crucial role in achieving a balance between capital market participants.
\end{abstract}

\section{Introduction}

Nowadays, stock exchange consists of two main components: primary market and secondary market. Secondary market is formed for formerly issued securities, namely for those that had been issued for primary market. Secondary market is also formed with two main components - stocks and market itself which gives owners of securities to reimburse them until profit has been gained (dividends or interests), as well as giving a possibility for negotiations or cash conversion's depending on propositions and current demand which, in turn, prove a certain value of those securities. It can be considered to be an absolute market, as we're bound to regulations of propositions and demand which demonstrates real demand of capital for state's economy. While researching such a complex question of speculative transactions, our main focus is concentrated on a question of their influence on functionality of stock exchange. Yet, arrival of speculators increases the number of participants in stock exchange transactions, thus promoting competition and, ultimately, more efficient detection of real value of economic subject. Stock trading is very attractive for those who are interested in a combination of excitement and the possibility of a large quick profit, and is an extraordinary opportunity for profit as process of trading itself appears to be technically simple.

\section{Methodological foundations}

Decent amount of scientific researches, written by both Ukrainian and foreign economists have been devoted to the problems of functionality of stock market and influence of speculative operations on investment capital. Increased interest in such operations is caused mainly due to their leading role in causing recent financial crises.

The basis for the integration of financial markets is the strong dependence of economies on each other. Market development plays an important role in the development of the country's economy and the stable growth of the economy [1]. Financial integration is a prerequisite for increasing market efficiency $[2,3]$. In turn, this reduces the diversification benefits available to investors. Monitoring the process of financial integration allows us to measure the economic interdependence, as well as to obtain the necessary information for investors $[4,5]$. According to authors of paper [6], it is clear that the nonextensibility of the share of alternative investments in the institutional investment portfolio may be due to the optimization of historical data. The period of stagnation since the 1990s, and the growth of the securities market, has become somewhat dramatic [7]. Insider trading has been a topic of interest for many researchers and it has been found that insider trading reduces liquidity and increases trading costs [8-12]. Also, there are studies (Sahoo and Kumar; Xiao et al) that are focused on the price discovery in the commodity futures market with mixed findings [13-18]. Researchers (De Angelis and Ravid) believe that hedging of commodity output and hedging of commodity input are different [19]. They think that firms with market power that hedge output have an

\footnotetext{
Corresponding author: george.abuselidze@bsu.edu.ge
} 
incentive to use the redundant method and distort market prices. In addition, studies (Asche et al; 2016) suggest that supply elements are significant for pricing forward contracts because convenient revenue in salmon forwards is connected to production variables [20].

\section{Results and Discussion}

Stock trading is very attractive for those who are interested in a combination of excitement and the possibility of a large quick profit. Firstly, it is an extraordinary opportunity for profit. Secondly, process of trading itself appears to be technically simple. The only thing required is to call your broker with certain orders. In several minutes, what he was told to do will be done. Thousands of broker organizations, as well as independent brokers, exist and ready to assist their clients' trading operations. Thirdly, stock operations stimulate intellectual activity, as they give an opportunity to analyze market tendencies and to predict how it may change. Stock exchanges are quite interesting and informative by it's nature. First feature that speculates reveal for themselves - there are few events that do not influence prices for securities or currencies. Speculations on stock market make people, whose only wish is to gain profit, more knowledgeable about the world they live in. Securities market is tightly connected to capital market, currency market and financial market, as, traditionally, these places have financial activity.

Interconnection of securities market with other markets (see Fig.1).

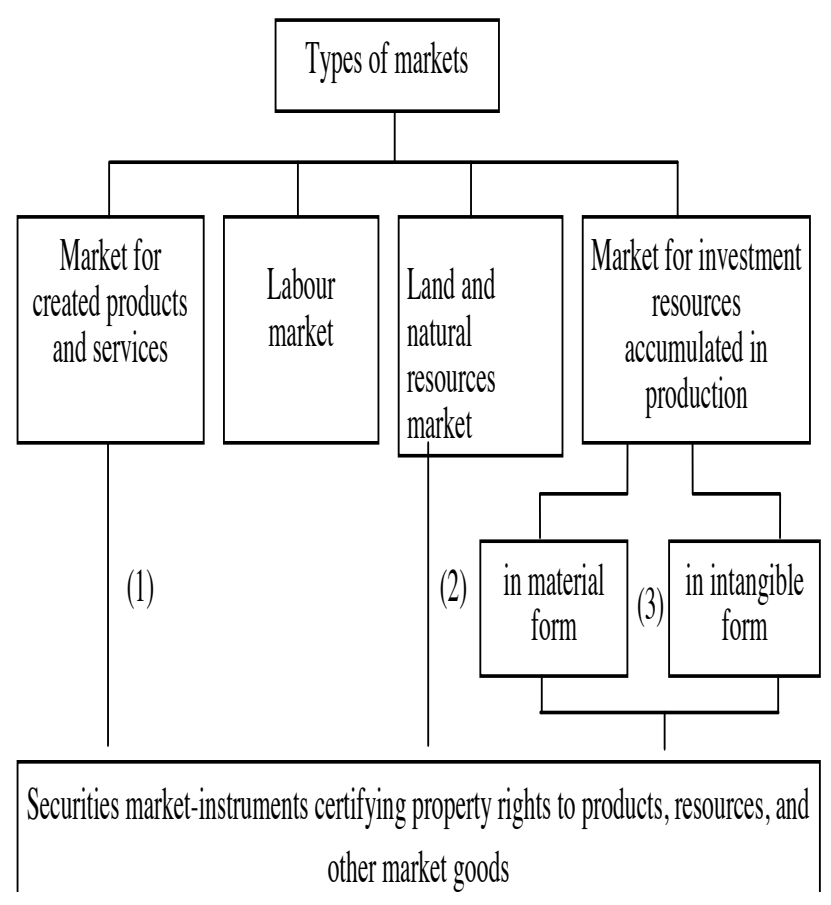

Fig. 1. Type of markets [21]

Primarily, obligations, stocks and government debt obligations, as well as their variations, are being main types of securities issued in stock exchange. The process of issuing securities for quoting on stock exchange is called "listing"; it is carried out in accordance with specific requirements for their issuer. Securities that have been listed and allowed to be bought or sold are being referred as stock asset. They are being traded by batches for certain price or by types; if trading by types, operation is being carried by correspondence, when these securities are absent on stock market [22].

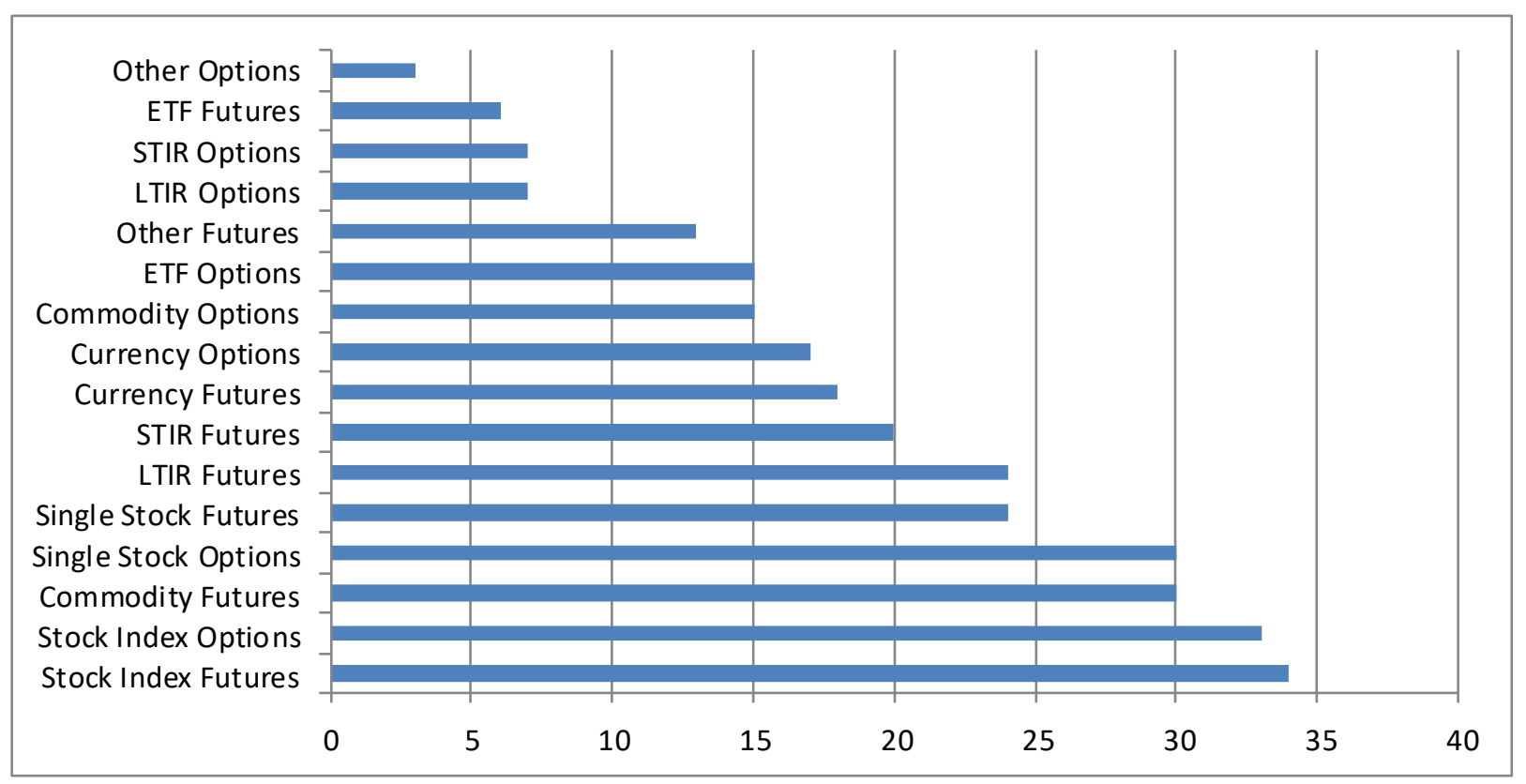

Fig. 2. Volumes of trading operations by types of instruments in $2019, \%$ Source: Made by author using following data [31] 
According to World Federation of Exchanges ("The WFE") data of 2019 year, comparing with results of 2018:

- Total domestic market capitalization at the end of 2018 was $22.6 \%$ higher than at the end of 2019 , reaching a new record high of 87.1 trillion dollars, which is the highest score during the five-year period observed on global and regional levels. This increase was due to the growth of domestic market capitalization in all regions: America by $17.8 \%$, Asia Pacific by $27.6 \%$, and EMEA by $24.3 \%$ by 2019 .

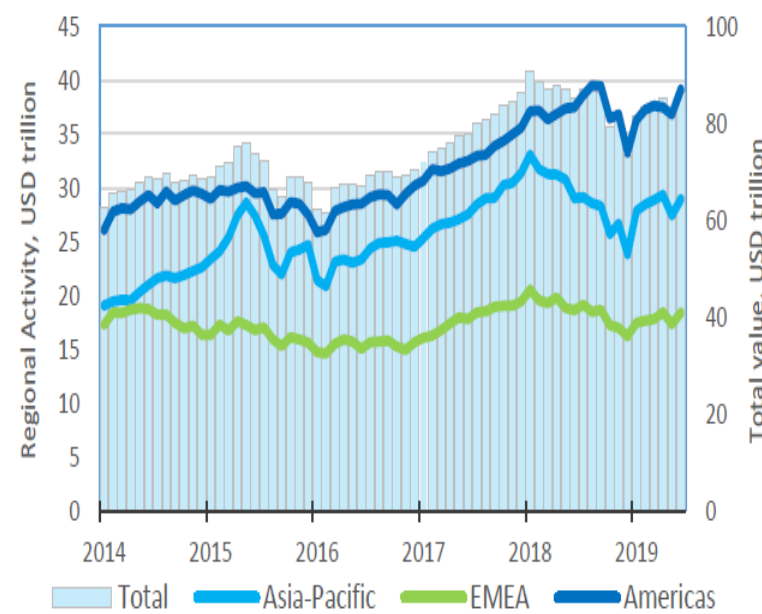

Fig. 3. Trading volumes in 2014-2019,\%

Source: Focus [23]

This increase in domestic market capitalization was accompanied by a synchronized global recovery of GDP growth, continuous favorable monetary policy in many regions, low inflation, low market instability, recovery in commodity prices and strong corporate profitability [24, 25].

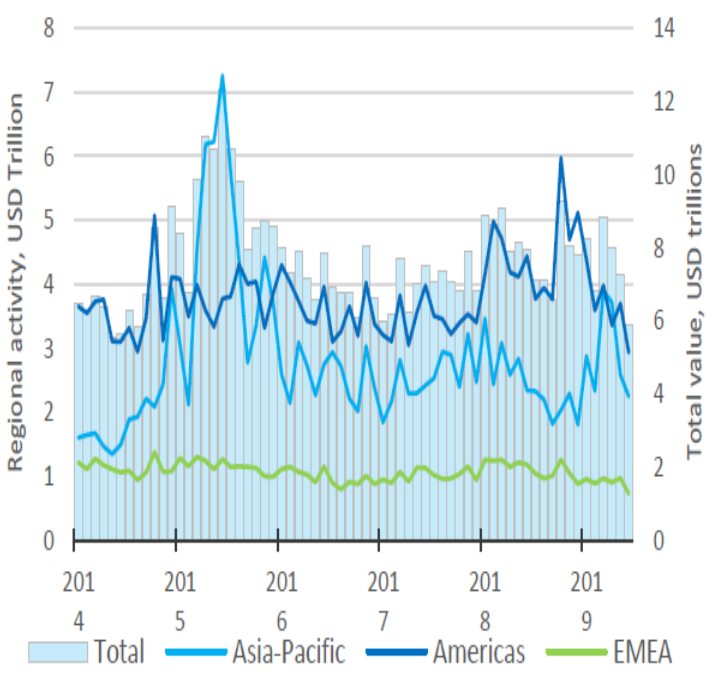

The analysis of the securities market of Ukraine shows changing dynamics of its development. This phenomenon can be traced to volume of trade during 2015-2019. It is impossible not to pay attention to the volume of exchange trade, as the stock market clearly reflects changes in the country's economy through the volume of trade and changes in securities prices (see Fig. 4).

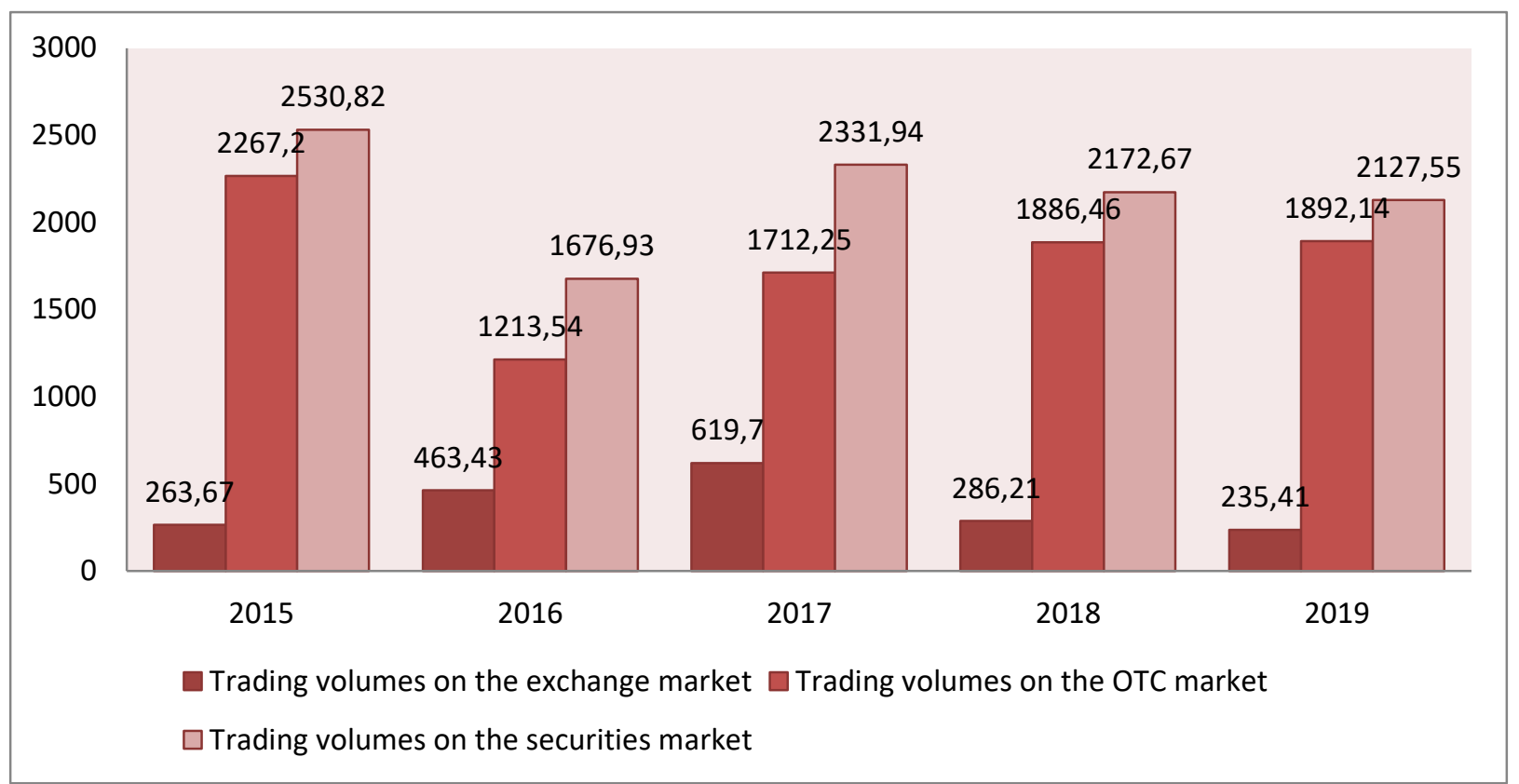

Fig. 4. Volume of trades on the securities market in 2015-2019, UAH billion Source: Made by author using following data [31] 
During the period of January-August 2019, the volume of stock exchange contracts with the secondary market trade organizers reached mark of $98.30 \%$ of the total volume during the specified period.

The highest volume of trading operations using financial instruments on trade organizers in 2018 recorded with government bonds of Ukraine - 210.08 billion UAH. This is $89.24 \%$ of the total volume of exchange transactions on stock exchanges in 2018.

The presence of a large group of speculators in stock markets leads to benefits both for stock markets and the economy as a whole. Speculators are an important source of market liquidity. The constant influx of orders of speculators in the trading hall can significantly reduce time of appearance of counter orders for acquirement or sellment of securities. On a liquid market with a large number of economic subjects, you can carry out transactions at any scale with a slight change in prices. At the same time, the arrival of speculators, increasing the number of participants in transactions, promotes competition, and, ultimately, leads to more effective detection of the objective course.

The activity of speculators contributes to relative stability of the market and generally eliminates price fluctuations, as the operations of speculators are often directed "against the market", or, in other words, against the main current price trend. By buying assets for low prices, speculators contribute to increased demand, which leads to higher prices. The sale of assets by speculators at high prices reduces demand and, consequently, prices. Therefore, extreme fluctuations of prices, possible in any other conditions, are mitigated by speculative activity [26].

On each stock exchange, speculators are being represented by two main types: "shorting" players "bullying" players. Some make a profit by raising rates, others - by "shorting" them. Speculation can be carried out on stock exchange both in cash and in urgent transactions. But cash transactions have fewer combinations and, thus, are generally less profitable. Therefore, the main arena of speculators is the futures market.

The difference between speculation in the cash and futures markets is following:

- In cash market, the speculator has the right to apply only when raising rates; speculation on the decline is impossible;

- With a cash transaction you cannot acquire more securities than are currently present on sale, so speculation in this market is limited by quantity of securities.

The game on shorting is carried out by selling shares by speculators in order to further purchase them at a lower price. The speculators involved in these operations are called "bears". The game of promotion is carried out by buying securities for resale at a higher price. Speculators of this type are called "bulls".

Speculative profits are possible both when playing "bully" and when "shorting". At the same time, it should be emphasized that speculative transactions may bring losses, and, oftener - very significant one. Therefore, engaging in speculative activities and investing in it may be quite a risky decision.

To some extent, speculators can be classified by differences in methods of forecasting market conditions that they use. Thus, one group of speculators uses fundamental market analysis, i. e. focuses on changing the factors that determine supply and demand in the market. Another group uses applied analysis, i. e. based on information on price dynamics, transaction volumes, interest rate levels, price dynamics, transaction volumes, interest rate levels [27].

Successful operations require two conditions - analysis and forecasting of prices, as well as the ability to effectively manage the capital allocated to the operation. For successful speculative trading, a trader must, firstly, specialize in any securities and, secondly, limit the number of simultaneous transactions. The number of simultaneous transactions is set considering the time that the trader can devote to speculative activities. For nonprofessional speculators who do not have the opportunity to devote all their time to this occupation, it is considered prudent to have no more than five operations simultaneously. For professional traders, who have special equipment and staff, this limit can be a hundred or even more transactions.

Those of professional traders who manage clients' money must strictly adhere to discipline which prescribes how to quickly eliminate losing positions. This contributes to the fact that the losses possible on each individual position are more than offset by the profit on other positions. However, like any other type of aggressive investment, stock transactions do not provide a steady increase in capital over time, and periods of recovery even for a very good trader can alternate with recessions. Such declines are not important for long-term investors, because they care about the end result - an increase in capital in a year or several years [28].

Tactics of operations and competent management of available monetary resources play a very important role in successful stock trading. Of course, effective capital management will not be able to provide a profit while enacting wrong decisions, but will help mitigate the impact of unprofitable transactions for the speculator.

The choice of the moment of entering into the agreement is one of the most crucial criteria on which depends its success or failure. The condition for determining the optimal term for concluding an agreement is a correct assessment of the duration of the expected price development: the tendency for decreasement or increasement, the interval of possible price fluctuations. According to empirical estimates, in more than $70 \%$ of cases speculators made some mistakes when entering the market: often the data on the further development of prices were taken into account either only partially or misinterpreted. At the time of concluding the agreement, the ratio of cash and forward exchange rate was often too unfavorable. Many speculators underestimated the likelihood of risk associated with urgent transaction.

The main transactions carried out on the stock market are mainly speculative in nature and are classified into two groups: "spot trading" operations and "forward 
trading" operations. "Spot trading" operations are the exchange of securities for certain amounts of money at the existing price of the exchange on the day of the transaction, accepted by the participants of that time [22]. These transactions are described as a person who has placed locks for sale or sale related to trading or other periods of time of partners selling securities or amounts. Thus, an investor can acquire securities if he can pay the same day (or others) in full. The client who sells "cash", is ordered to deliver the contract on securities at the same time, will receive their value on an open account in the joint stock company (broker of legal entities). Typically, these transactions are carried out by measuring changes in the portfolio or processing of financial assets to be kept in cash. In addition, it can be a speculative goal, when several quotes are performed in different markets, where securities are quoted differently, resulting in gains from the price difference in favor of the operator.

"Forward trading" or "Futures trading" is characterized by the fact that participants are obliged to fulfill their obligations within a certain period, beginning from the date of the transaction, but the price is determined by the date of transaction complement. Forward transactions are, in fact, speculative, as the main purpose of operators is not the actual receipt or transfer of securities, but to gain profit due to a favorable difference in the exchange rate between the date of its completion and its maturity [29].

As a tool, which purpose is to attract investment opportunities, speculation plays a crucial role in achieving a balance between financial market participants. Hedge funds are designed to eliminate market imbalances, adjust interest rates or exchange rates. The stock market recognizes speculation as a prerequisite for proper functioning. The ultimate goal is to place exchange trades in securities, divided into four categories: simple investments, securities arbitrage, hedging transactions and speculation on the stock exchange.

Simple investments mean investing available capital (individuals or firms) in stock markets by buying or selling securities. These securities are represented by target securities (shares), fixed income securities (bonds) and other shares. Such investments are made to generate income in the form of dividends or interest, or in the form of capital gains. An investor who places available capital on the stock markets expects better use of this capital, but at the same time he knows that these investments are subject to a certain risk, which usually becomes greater when potential investment becomes more profitable. The main way to reduce this risk is diversification. Therefore, a balanced investor will place its funds in more securities than just one, thereby offsetting the losses caused by certain securities with the income received from others. Therefore, the investor will build an efficient and balanced securities portfolio in accordance with certain basic principles, among which we mention a detailed analysis of the securities portfolio, constant supervision and better information on the development of the stock market [30].

Securities arbitrage is aimed at making a profit by making a number of investments, namely by purchasing securities in a market where the stock level is lower, followed by simultaneous or immediate sale in another market where the value is higher. Arbitrage is considered risk-free, so investors can satisfy small returns. Unlike speculation, arbitrage is based on stock prices of already known securities, not on valuations, so it cannot be completed other than with profit. Arbitrage should not be limited to obtaining positive differences for the same securities at one time, but it should also receive profits from different arbitrations in securities and for longer periods.

If the general situation in the economy tends to deteriorate, it will arbitrage stocks for bonds (indexed if we are linked to inflation). Eventually, if the situation begins to recover, it will arbitrage shares for obligations [31]. It is good to note that arbitrage is not available to anyone; it is designed specifically for exchange specialists or those who work in the exchange system, who have access to information tools and always support changes in stock prices while trading in several markets.

Hedging transactions are transactions in which the originator intends to cover itself from the risks of changes in stock market prices. In practice, however, hedging is the protection of an investor's securities in an unstable market, made not for profit. Thus, with the help of these hedging operations, it allows brokers and investors to avoid losses during period of turbulence, as well as the chances of making a profit.

Even if the purpose of hedging differs from the purpose of the speculators, this technique is the same as in the case of speculation, when one of the partners involved in the transaction wins and the other loses, resulting in losses and profits being transferred. In this case, at a time when the sale of shares is at risk, those who want to cover the speculative fund will start trading under the same conditions, but vice versa.

Therefore, the buyer of certain securities will also become a seller of speculators for the same securities, and the seller will become a buyer of speculators.

Speculative stock market transactions are successful sales - the purchase of securities transactions aimed at making a profit from the difference in stock prices. The basic principle is in any speculative business: buy low and sell high. What characterize stock-based speculation is the profit that the speculator turns to and the risk that he consciously assumes. This risk stems from the fact that the speculator cannot accurately predict the issuance of currency.

In many cases, the distinction between simple investment and speculation is difficult, although goals differ. Through simple investments, we are willing to generate income and investment security. However, simple investment, which we use to acquire securities for safekeeping, will be speculated if these securities are quickly sold for profit, the same happens in the opposite case. Following types of speculators exist:

- Those who speculate on fluctuations of exchange rates for a certain period;

- Those who speculate on changing course from one day to another;

- Long-term speculators who target exchange rate changes recorded for a longer period of time (months, years) of permanent speculators [32]. 
The end goal of any existing speculator is to maximize the return on the stock exchange of any completed transaction, knowing and expecting that this will happen as a result of risks he assumes. From this point of view, the speculator will be ready at any time to "get rid" of any securities that he personally does not trust, seeking to place them to less savvy investors.

Practically, two main types of speculation, depending on the evolution of the stock price, exist:

- "On drop" speculation - a case where the speculator believes that the stock price will fall and, therefore, will give an order to sell futures. If his forecasts are confirmed (the rate decreases), by the end of the contract he will purchase the securities through a transaction on the spot (within a specified period) and transfer it to the buyer. Thus, the speculator gets profit from difference of the two stock rates;

- Speculation "on growth" - when a speculator assumes that the stock rate will increase and, consequently, will give orders to buy futures. In the event that such a rate increases, before the expiration of the contract, he will purchase securities at a previously set rate and make a sale in (on time).

The existence of well-informed speculators is beneficial for stock markets, as their activities eliminate stock market fluctuations, so investors who are interested in investing or selling are able to find a counteragent more easily. This is the fact that speculation in the stock market is necessary, and, conversely, it does not violate ethical rules if the profits of speculators are not free, but are the result of the risks that had been taken. The concepts of "speculator" and "player" are often misunderstood here. In general, a speculator is a prudent person, wellinformed, has a rich portfolio of knowledge in the stock market, focusing on rational predictment, and the "player" depends largely on success of his speculations. For comparison, an experienced investor will properly and effectively use both elements of rational economic analysis and understanding of his behavior, as well as behavior of other stock exchange subjects. Thus, he will be able to affect the efficiency of its portfolio less than a change to make of himself a memorable investor, who can easily influence the latest developments in his portfolio or market [33].

It is also worth mentioning that the consequences of certain operations that are aimed at artificially increasing or decreasing rates, spreading false rumors about the situation of certain companies, practices called excitement. These are transactions that contradict the rules of fair practice in the stock market. Those who use this sort of "hype" artificially do affect the rate of decline, and when the price reaches the desired low enough, they will acquire them and then sell at a higher price, after artificially raising the rate.

Regarding securities market manipulation, the European Securities Market Regulatory Committee (CESR) has issued a first handbook, the "Market Abuse Directive". This applies to recognized market practices, market manipulation and indications that CESR members consider market manipulation.

This is due to the fact that, in many cases, under the concept of speculation were hidden operations that appeared to be on the verge of legality, aimed at attracting investors to excessive risk, which ultimately proved unfavorable. Based on the extensive experience in this field, developed economies have issued a set of rules for managing listed issuers, providing reliable protection against speculative actions that may mislead investors, thereby protecting their funds and maintaining the positive nature of these speculative transactions. Therefore, the idea of market abuse is still relevant for the development of the Ukrainian market, especially if you look on a membership in the European Union, whose law and experience in the field of economics may be of a great interest to the Ukrainian capital market.

\section{Conclusions}

The development of the capital market provides the promotion of liquidity market capital, diversifies of the exchange system, increases access to long-term investment resources in country.

The proper functioning of the capital market, especially stock exchanges, as well as the avoidance of market abuse (in any form) are serious problems for market participants as well as for companies engaged in financial transactions, as it affects the real economy with certain chain reactions that have both of negative and positive effects. Although the importance of the speculative nature of the stock market cannot be challenged, a critical point of view still do exist - regarding the question of the ethical purpose of speculation, which for some is a wellestablished normality, and for others - a departure from the real economy and social or moral values as they are known on a conceptual level. However, speculation must be supported and regulated so that the long-term effects of such transactions do not affect the integrity of the market and the performance of its crucial functions.

\section{References}

1. G. Abuselidze, European Integration of Georgia and Financial-Economic Condition: Achievements and Challenges. European Journal of Sustainable Development $\quad 8(1), \quad 53-68 \quad$ (2019). doi:10.14207/ejsd.2019.v8n1p53

2. G. Abuselidze, Georgia's Capital Market: Functioning Problems and Development Directions in Association with European Union. Journal of Applied Economic Sciences 13(7), 1929-1938 (2018)

3. A. Slobodianyk, G. Abuselidze, L. Tarasovych, The mechanism of integration of the Ukrainian stock market in the world stock market. E3S Web of Conferences 157, 04034 (2020). doi:10.1051/e3sconf/202015704034

4. L. M. Yang, Z. Jason, Sh. Hamori, Dependence Structures and Systemic Risk of Government Securities Markets in Central and Eastern Europe: A CoVaR-Copula Approach. Sustainability 10(2) (2018). doi:10.3390/su10020324

5. G. Abuselidze, A. Slobodianyk, Investment of the financial instruments and their influence on the 
exchange stock market development, in Economic Science for Rural Development Conference Proceedings 52, 203-221 (2019).

6. G. Abuselidze, L. Beridze, The Role of Alternative Investments in the Development of Capital Markets: in Terms of the Transformation of Georgia with the $E U$, in Proceedings of the 4th International Conference on European Integration (ICEI) 29-41. VSB Techn Univ, Ostrava (2018).

7. O. Engdahl, Self-regulatory investments among private actors in the era of regulatory capitalism: the licensing of Swedish finance and securities industry employees. Crime law and social change 69(5), 577594 (2018). doi:10.1007/s10611-017-9766-3

8. P. Brockman, D.Y. Chung, Investor protection and firm liquidity. The Journal of Finance 58(2), 921-937 (2003)

9. R.P.H. Fishe, M.A. Robe, The impact of illegal insider trading in dealer and specialist markets: Evidence from a natural experiment. Journal of Financial Economics 71(3), 461-488 (2004). doi:10.1016/S0304-405X(03)00188-0.

10. I. A. Blank, Asset and capital management of the enterprise. Nika-Center, (1-448) (2003)

11. U. Bhattacharya, H. Daouk, The world price of insider trading. The Journal of Finance 57(1), 75-108 (2002)

12. J. Du, S.-J. Wei, Does insider trading raise market volatility? The Economic Journal 114(498), 916-942 (2004). doi:10.1111/j.1468-0297.2004.00249.x.

13. M.J. Bohmann, D. Michayluk, V. Patel, Price discovery in commodity derivatives: Speculation or hedging?. Journal of Futures Markets 39(9), 11071121 (2019). doi:10.1002/fut.22021

14. H. Geman, Commodities and commodity derivatives: modeling and pricing for agriculturals, metals and energy. John Wiley \& Sons. (2009)

15. L.J. Maynard, S. Hancock, H. Hoagland, Performance of shrimp futures markets as price discovery and hedging mechanisms. Aquaculture Economics \& Management 5(3-4), 115-128 (2001). doi:10.1080/13657300109380282

16. Q. Pei, D. D. Zhang, J. Xu, Price Responses of Grain Market under Climate Change in Pre-industrial Western Europe by ARX Modelling. Proceedings of the 4th International Conference on Simulation and Modeling Methodologies, Technologies and Applications. doi: $10.5220 / 0005025208110817$

(2014).

17. P. Sahoo, R. Kumar, Efficiency and futures tradingprice nexus in Indian commodity futures markets. Global Business Review 10(2), 187-201 (2009). doi:10.1177/097215090901000204

18. X. Xiao, Q. Tian, S. Hou, C. Li, Economic policy uncertainty and grain futures price volatility: evidence from China. China Agricultural Economic Review 11(4), 642-654 (2019). doi:10.1108/caer-112018-0224
19. D. De Angelis, S.A. Ravid, Input Hedging, Output Hedging, and Market Power. Journal of Economics \& Management Strategy 26(1), 123-151 (2016). doi:10.1111/jems.12180

20. F. Asche, B. Misund, A. Oglend, The spot-forward relationship in the Atlantic salmon market. Aquaculture Economics \& Management 20(2), 222234 (2016). doi:10.1080/13657305.2016.1156192

21. V. V. Andreeva, Stock market of Ukraine at the present stage of economic development. Science and higher education 2, (2014)

22. R. Mc Donald, Derivatives Markets. Addison Wesley, 1-881 (2016)

23. Focus. The World Federation of Exchanges publishes H1 2019 Market Highlights. https://focus.worldexchanges.org/articles/world-federation-exchangespublishes-h1-2019-market-highlights (2020)

24. G. Abuselidze, L. Mamaladze, The Impact of the COVID-19 Outbreak on the Socio-Economic Issues of the Black Sea Region Countries. Lecture Notes in Computer Science 12253, 453-467. Springer, Cham (2020). doi:10.1007/978-3-030-58814-4_32

25. G. Abuselidze, A. Slobodianyk, Pandeconomic Crisis and Its Impact on Small Open Economies: a Case Study of COVID-19. Advances in Intelligent Systems and Computing 1258, 718-728. Springer, Cham (2021). doi:10.1007/978-3-030-57450-5_61

26. J. C. Hull, Options futures and other derivatives. New Jersey: university of Toronto, Prentice Hall, Englewood Cliffs, 5 ed. (1-780) (2016)

27. R. W. Kolb, Financial Derivatives. 3rd Ed. New Jersey: John Wiley Sons, Inc. 1-323 (2016)

28. J. Marshall, Dictionary of Financial Engineering. John Wiley Sons, Inc. 1-289 (2016)

29. OECD Composite Leading Indicators. Turning Points of Reference Series and Component Series. OECD, 48 (2014)

30. The international banking market report. Statistical Annex.

http://www.bis.org/publ/qtrpdf/r_qa1 106.pdf\#page=1 14. (2011)

31. The world federation of exchanges. 2017 full year market highlights. https://www.worldexchanges.org/home/index.php/news/worldexchange-news/the-world-federation-of-exchangespublishes-2017-full-year-market-highlights

32. O, Baula, Prospects for integration of the domestic securities market into the world stock market. Economic forum 2, (2014)

33. A. I. Berlach, Exchange law of Ukraine. University "Ukraine", 1-316 (2012) 